\title{
ARMY EXPERIENCE OF SYPHILIS THERAPY
}

\author{
C. C. M. JAMES, DONALD G. MACKAY, and J. T. WRIGHT
}

\section{INTRODUCTION}

The prevention of syphilis is a major problem of social medicine; and its prevention is closely interlocked with the efficacy of treatments available. For this reason it is surely appropriate in this context to examine new sources of information with respect to its therapeutic control as a pre-requisite to consideration of other methods of eliminating the disease. Experience of syphilis therapy in the Army during the late war provides unique materials for assessing therapies in current use, and it is the aim of this communication to assess their value.

During the first phase of the war, Army medicine relied exclusively on long-term arsenotherapy with bismuth. Later a certain number of cases was treated by means of short-term mapharside with bismuth. In the last phase penicillin treatment replaced or supplemented the use of arsenicals for a trial period pending the outcome of experience. In all, we are in a position to examine the results of eight procedures which we specify more fully below (part 5):

1. $2 \cdot 4$ mega units of penicillin.

2. 4.0 mega units of penicillin.

3. $2 \cdot 4$ mega units of penicillin $+0.6 \mathrm{~g}$. mapharside.

4. $2 \cdot 4$ mega units of penicillin $+0 \cdot 4 \mathrm{~g}$. mapharside +1.0 g. bismuth.

5. Long-term arsenic therapy, high aggregate dosage.

6. Long-term arsenic therapy, low aggregate dosage.

7. Long-term arsenic therapy $+2 \cdot 4$ mega units of penicillin.

8. Short-term arsenic therapy.

\section{SOURCES OF MATERIAL}

Long-term arsenic cases were traced through the War Office Central Card Index which supplied a nominal roll of all syphilis cases admitted to hospital for treatment during the twelve months 1943-4. The same nominal roll also served for a survey of post-arsphenamine jaundice (Truelove and Hogben, 1947). Nominal rolls obtained from the Adviser in Venereology made it possible to trace cases undergoing initial treatment (by methods later specified) at Army Special Treatment
Centres in Britain during the period September, 1944, to June, 1946. During this period each Special Treatment $\vec{\omega}$ Centre (S.T.C.) was treating all cases of early syphilis $\stackrel{\omega}{\mathcal{S}}$ with a standard schedule of therapy notwithstanding the $\vec{\varnothing}$ duration or severity of the disease. Hence such nominal $\stackrel{\rho}{工}$ rolls should provide an unbiased sample of the total i Army early syphilitic population at home. By recourse to the serial numbers supplied by them, it was possible $\vec{\infty}$ to extract hospital record cards (A.Fs. I.1220) from the 0 Central File of Medical Documents at the War Office? and from the Central Syphilis Register (C.S.R.). The C former furnished detailed information with reference to initial syphilitic infection and treatment. The latter supplied surveillance notes relating to each case.

Many cases on the nominal rolls from S.T.Cs. were unserviceable for the following reasons:

(1) patients from other Services, initially treated in military units were subsequently transferred from Army supervision;

(2) some patients had had previous treatment for the disease;

(3) some cases were congenital, tertiary, neurosyphilitics, or latent syphilitics;

(4) relevant documents of a small group were $\overrightarrow{\overrightarrow{0}}$ incomplete:

All cases under consideration are early. They had neither suffered previously from the disease nor under-? gone previous treatment, but otherwise include any $\frac{1}{10}$ diagnosed as sero-negative primary syphilis, sero- $\frac{\rho}{?}$ positive primary syphilis, and early secondary syphilis. $\dot{0}$ The diagnostic criterion of primary cases was presence 3 of a primary chancre confirmed by detection of Treponema ${ }^{\circ}$ pallidum by dark-ground examination, with or without 3 positive serological test (Wassermann or Kahn). That 0 of secondary syphilis was a positive Wassermann or $\mathrm{J}$ Kahn test together with such clinical manifestations as a rash, mucous patches, or condylomata (confirmed as such by dark-ground examination).

\section{Criteria of Efficacious Treatment}

Inter alia we may judge the therapeutic efficacy of a drug in terms of the risk of relapse, or the frequency of beneficial response whether temporarye or otherwise. Accordingly, we here distinguish two categories of cases as relapses and failures, the ${ }^{-}$ former among whom the benefit of treatment is -0. only temporary, the latter because they fail to derive any manifest benefit at all. Any index which combines figures referable to both criteria is neces- $\varrho$ sarily arbitrary, because we have no reason to 
suppose that a treatment which is accredited by a lower relapse rate will be accredited by a lower failure rate; and if the two methods of assessment point to different conclusions, no formula applicable to all diseases prescribes which should have priority. Since we cannot compute relapse rates without excluding cases which at no time responded to treatment, we have thus to apply to our data two independent criteria of efficacy: ( $a$ ) what proportion of all cases treated fail to respond at any time; (b) among cases which do respond at some time, what proportion subsequently relapse.

Considerations which did in fact guide our classification of cases as failures, relapses, or cures, call for more explicit clarification. Both for diagnosis and for surveillance, treatment centres concerned in the present investigation employed the qualitative Wassermann reaction (W.R.), the qualitative Kahn test (K) and quantitative Kahn test (K.Q.). Owing to exigencies of the Service, the W.R. and Kahn were not always used together in surveillance; but quantitative Kahn tests (K.Q.) performed in the majority of cases give evidence of serological trends. We here consider a serum to be positive when the laboratory reported any one of the following: W.R.,$+ \mathbf{K}+$, or K.Q. of four or more units. We classify as doubtful a result such as $K \pm$, W.R. \pm , or K.Q. readings of less than four units. Blood samples from each case were commonly examined both at beginning and end of treatment. The routine of surveillance entailed clinical and serological examination at $2,4,6,9,12,15,18$, and 24 months after completion of treatment. Lumbar puncture was performed at 6,18 , and 24 months.

We here regard a case as cured, if it conforms to cach of two criteria: (a) all lesions have healed at the conclusion of treatment; $(b)$ the serological test is negative at the end of surveillance. We also regard as a cure, any case ending surveillance prematurely with one sero-negative test (e.g. W.R.) and one doubtful (e.g. Kahn) if it satisfies each of the following criteria: (a) there has been consistent decline from an originally high titre; $(b)$ there are no remaining clinical signs of syphilis. Clinical records (A.Fs. I.1220) provide the information on which we rely for specification of relapse in accordance with either of the two criteria on which we base the initial diagnosis, viz. (a) presence of fresh clinical manifestations in which Treponema pallidum could be demonstrated; (b) positive serological test, if previous tests had been negative or of lower titre. Reappearance of muco-cutaneous lesions in which Treponema pallidum is demonstrable provides clear-cut evidence of relapse; but the serological criterion is not, of itself, unequivocal.

Many cases lost in the follow-up (defaulters) were not sero-negative at the time. They were either sero-positive or serologically doubtful; and their previous serology may have been: (i) positive with a steady or rising titre; (ii) positive with a declining titre; (iii) consistently or at some time negative. Cases we classify as failures, in contradistinction to relapses, are cases which did not become seronegative within four months of the end of treatment but continued with a high titre or an increasing titre until they were lost to surveillance. In this context failure therefore means inefficacy of 'a treatment to reverse or to reduce the serological titre by the fourth month. There were few among the long-term arsenic series, and only among such as received small aggregate doses of arsenic owing to supervening dermatitis or jaundice. In the penicillin and short-term arsenic series some failures renewed treatment as soon as there was clear evidence of defective response. The rest would almost certainly have been re-treated, had they not defaulted.

Cases defaulting from surveillance with a titre still positive but steadily declining from an initially high level are obviously doubtful. Cases with a positive serum after one or more clear-cut negative tests during surveillance are by definition relapses at the month in which they become positive. Others classified as doubtful had a doubtful serum reaction at their last surveillance before they defaulted, because further surveillance might have demonstrated a steadily rising titre or fresh muco-cutaneous lesions indicative of relapse. In a very few instances, a weakly positive serum reaction interrupted an otherwise consistently negative surveillance. The subsequent negative clinical and serological trend, confirmed by absence of abnormality in the cerebrospinal fluid, suggested that such isolated positive

TABLE I

Percentage of Cases ending with an Equivocal SEROLOGY REJECTED FROM THE SERIES ON ACCOUNT OP FOLLOW-UP OF LESS THAN FOUR MONTHS

\begin{tabular}{|c|c|c|c|c|}
\hline & \multicolumn{2}{|c|}{$\begin{array}{c}\text { Primary } \\
\text { Sero-positive }\end{array}$} & \multicolumn{2}{|c|}{ Secondary } \\
\hline & $\begin{array}{l}\text { Total } \\
\text { cases }\end{array}$ & $\begin{array}{l}\% \text { cases } \\
\text { rejected }\end{array}$ & $\begin{array}{l}\text { Total } \\
\text { cases }\end{array}$ & $\begin{array}{l}\% \text { cases } \\
\text { rejected }\end{array}$ \\
\hline $\begin{array}{l}\text { Pen. } 2.4 \ldots \\
\text { Pen. } 4.0 \ldots \\
\text { Pen. and Maph. } \\
\text { Pen. and Maph. } \\
\begin{array}{l}\text { +Bismuth } \\
\text { LTA. and Pen. }\end{array} \\
\text { LTA. (A) } \\
\text { LTA. (B) } \\
\text { STA. . . } \\
\text {. . }\end{array}$ & $\begin{array}{r}163 \\
44 \\
113 \\
\\
92 \\
38 \\
84 \\
84 \\
38\end{array}$ & $\begin{array}{l}0 \cdot 0 \\
6 \cdot 8 \\
2 \cdot 7 \\
3 \cdot 3 \\
0 \cdot 0 \\
0 \cdot 0 \\
0 \cdot 0 \\
0 \cdot 0\end{array}$ & $\begin{array}{r}119 \\
30 \\
59 \\
56 \\
26 \\
67 \\
47 \\
42\end{array}$ & $\begin{array}{r}0 \cdot 8 \\
6 \cdot 7 \\
10 \cdot 2 \\
14 \cdot 3 \\
0 \cdot 0 \\
0 \cdot 0 \\
2 \cdot 1 \\
0 \cdot 0\end{array}$ \\
\hline
\end{tabular}


reactions were either of the falsely positive type or were due to laboratory errors. Little can be predicted of a case which defaults from surveillance at the second or third month with a serum still positive or doubtful and without any stigmata of clinical relapse. Since the time under surveillance is quite inadequate to disclose the ultimate trend, we have rejected them from our pool of data. Table I shows the percentage of all cases available for follow-up in each series and those rejected for reasons here stated.

In therapeutic trials involving a communicable disease a common difficulty arises in connexion with delimitation of relapses and re-infections. Eightyfive cases in all treatment groups of our series were known to develop additional syphilitic lesions. The venereologist's opinion as stated in the clinical records distributes the later lesions as follows:

$$
\begin{array}{llll}
\text { Relapses } & \ldots & \ldots & 33 \\
\text { Reinfections } & \ldots & \ldots & 12 \\
\text { Inconclusive } & \ldots & \ldots & 40
\end{array}
$$

It has hitherto been customary (Moore, 1943) to exclude a diagnosis of reinfection unless consonant with all of the three following criteria: (i) " There must be proof that the patient had syphilis prior to the occurrence of the suspected second infection, and this proof must rest on the demonstration of spirochaetes in a lesion or the occurrence of a positive blood Wassermann reaction in the blood serum, and not on clinical judgment alone."

(ii) "After an interval following antisyphilitic treatment and at a site other than that of the primary lesion of the first infection, there must develop a lesion with the characteristics of a chancre in which spirochaetes can be demonstrated."

(iii) "That at the time of the supposed second infection the serologic test is negative; and that while under observation and during a period in which treatment is purposely withheld, the serologic test becomes positive or the patient develops outspoken secondary syphilis."

The clinical records of our cases do not indicate $\stackrel{p}{\oplus}$ that the venereologist's opinion relied on the

\section{CUMULATIVE PERCENTAGE RELAPSE RATES}

2.4 MEGA UNITS PENICILLIN

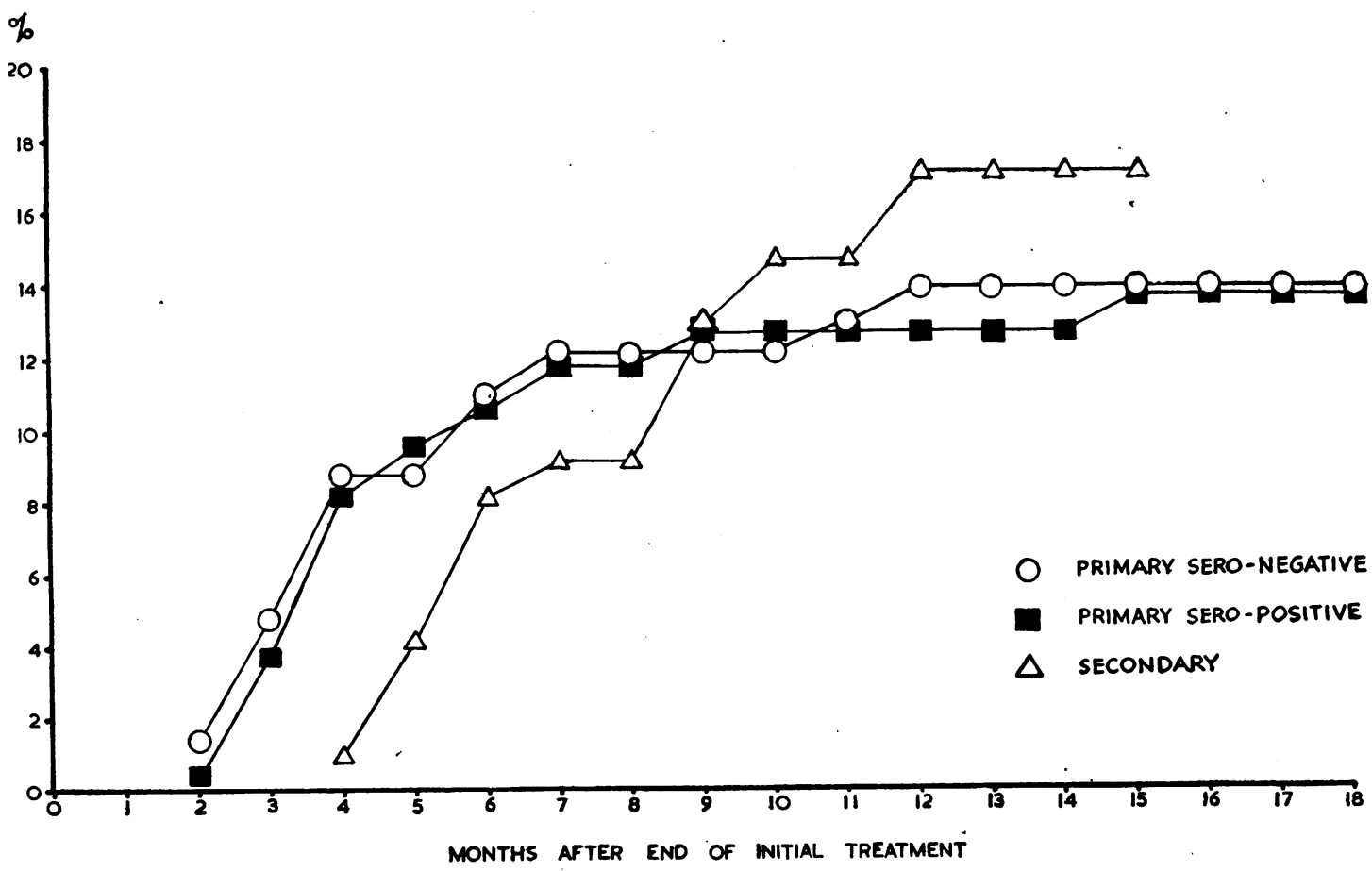

MONTHS AFTER END OF INITIAL TREATMENT 
coincidence of these three criteria. The first of Moore's criteria (i) was indeed fulfilled in all our cases; but analysis of the sample on the basis of the other two yielded the figures given in Table II.

TABLE II

\begin{tabular}{c|c|c|c|c|c}
\hline & Sore at original site & \multicolumn{2}{|c|}{ Sore at new site } & Total \\
\cline { 2 - 5 } & Sero-pos. & Sero-neg. & Sero-pos. & Sero-neg. & \\
\hline $\begin{array}{r}\text { Cited as } \\
\text { relapse }\end{array}$ & 28 & 3 & 2 & 0 & 33 \\
$\begin{array}{c}\text { Cited as } \\
\text { r e i n } \\
\text { fection }\end{array}$ & 3 & 2 & 6 & 1 & 12 \\
$\begin{array}{c}\text { N o n } \\
\text { c o m }- \\
\text { mittal }\end{array}$ & 26 & 7 & 3 & 4 & 40 \\
\hline Total & 57 & 12 & 11 & 5 & 85 \\
\hline
\end{tabular}

Records usually laid emphasis on a history of recent exposure where citing a diagnosis of reinfection. It is reasonable to assume that the 57 cases whose second lesions appeared at the site of the original chancre with coincident positive serum reaction were definite cases of muco-cutaneous relapse. Probably, the 12 cases which were seronegative when a second lesion appeared on the original sites were also muco-cutaneous relapses. Inter alia, Rabut and Hudelo (1924) described 21 such cases in a series of 51. Muco-cutaneous relapse in the presence of a negative or doubtful serum is thus well accredited. The 11 cases whose second lesions were stated to have occurred at different sites from the original chancres at a time when the serum was positive are more difficult to assess. It was clear from the notes of some that the new lesions were sufficiently close to be within the lymphatic watershed of the original site, a fact which might well suggest that they were probably muco-cutaneous phenomena. On the other hand, records of one or two with typical chancres proved to contain Treponema pallidum at a site well away from the original chancre and associated with enlargement of lymph glands other than those stated to be enlarged in the original infection, cite a doubtful serum reaction. It is conceivable that such cases were, in fact, reinfections. Of the five remaining cases, none fully satisfies the criteria advanced by Moore. We therefore regard them as relapses, and cite further details with reference to them in Table III.

The evidence that the second sore differed significantly in respect of site from the initial chancre is poor in cases 1, 2, and 4. In case 3, the new lesion was apparently still within the lymphatic watershed of the initial chancre. Case 5 is the only one in which a negative serum reaction in the presence of the second sore was observed to have become positive before further treatment was instituted. Unfortunately, dark-ground examination was not done until the sore had been present for one month. It was then negative on three occasions. In no case was there evidence that " repeat" blood tests had been used to confirm routine tests.

\section{Calculation of Relapse Rates}

All time periods date from the end of the course of treatment. In what follows, the assumption is that we have sorted our data to exhibit:

(a) numbers of sero-negative individuals $\left(\mathrm{x}_{\mathrm{m}-1}\right)$ still under observation at the beginning of the $m$ th month from date of certification;

(b) ditto $\left(\mathrm{x}_{\mathrm{m}}\right)$ still remaining under observation at the end of the $m$ th month;

(c) relapses $\left(\mathrm{y}_{\mathrm{m}}\right)$ during the $m$ th month;

(d) defaulters $\left(d_{m}\right)$, that is, individuals who have ceased to be under observation during the $m$ th month.

The last item is evidently deducible from the others by the relation:

$$
\mathrm{d}_{\mathrm{m}}=\mathrm{x}_{\mathrm{m}-1}-\mathrm{x}_{\mathrm{m}}-\mathrm{y}_{\mathrm{m}} \ldots \ldots \ldots \ldots \ldots \text { (i) }
$$

Our problem is to ascertain the chance of relapse during the $m$ th month, denoted below as $\mathrm{q}_{\mathrm{m}}$. If there were no defaulters, this would be the ratio of relapses during the month to sero-negative individuals at the beginning, that is, $y_{m} \div x_{m-1}$; but $d_{m}$ defaulters would have accounted for an unascertained number $\left(e_{m}\right)$ of relapses during the same period, so that the correct value is given by:

$$
\mathrm{q}_{\mathrm{m}}=\frac{\mathrm{y}_{\mathrm{m}}+\mathrm{e}_{\mathrm{m}}}{\mathrm{x}_{\mathrm{m}-1}}
$$

Our problem is therefore to estimate $e_{m}$. Let us suppose that all the $d_{m}$ individuals had ceased to be available for further observation on the first day of the $m$ th month after reporting for the census recording $x_{m-1}$ sero-negative individuals at that date. If $s o, e_{m}$ would be the relapses during the month referable to an initial population of $d_{m}$ sero-negative individuals, i.e.

$$
q_{m}=\frac{e_{m}}{d_{m}} \text { or } e_{m}=q_{m} d_{m}
$$

In fact, we are entitled to assume that the stream of defaulters is steady, the mean time during which they were available for observation being $\frac{1}{2}$ a month. We may therefore put approximately

$$
e_{m}=\frac{1}{2} q_{m} d_{m}
$$


C. C. M. JAMES, DONALD G. MACKAY, AND J. T. WRIGHT

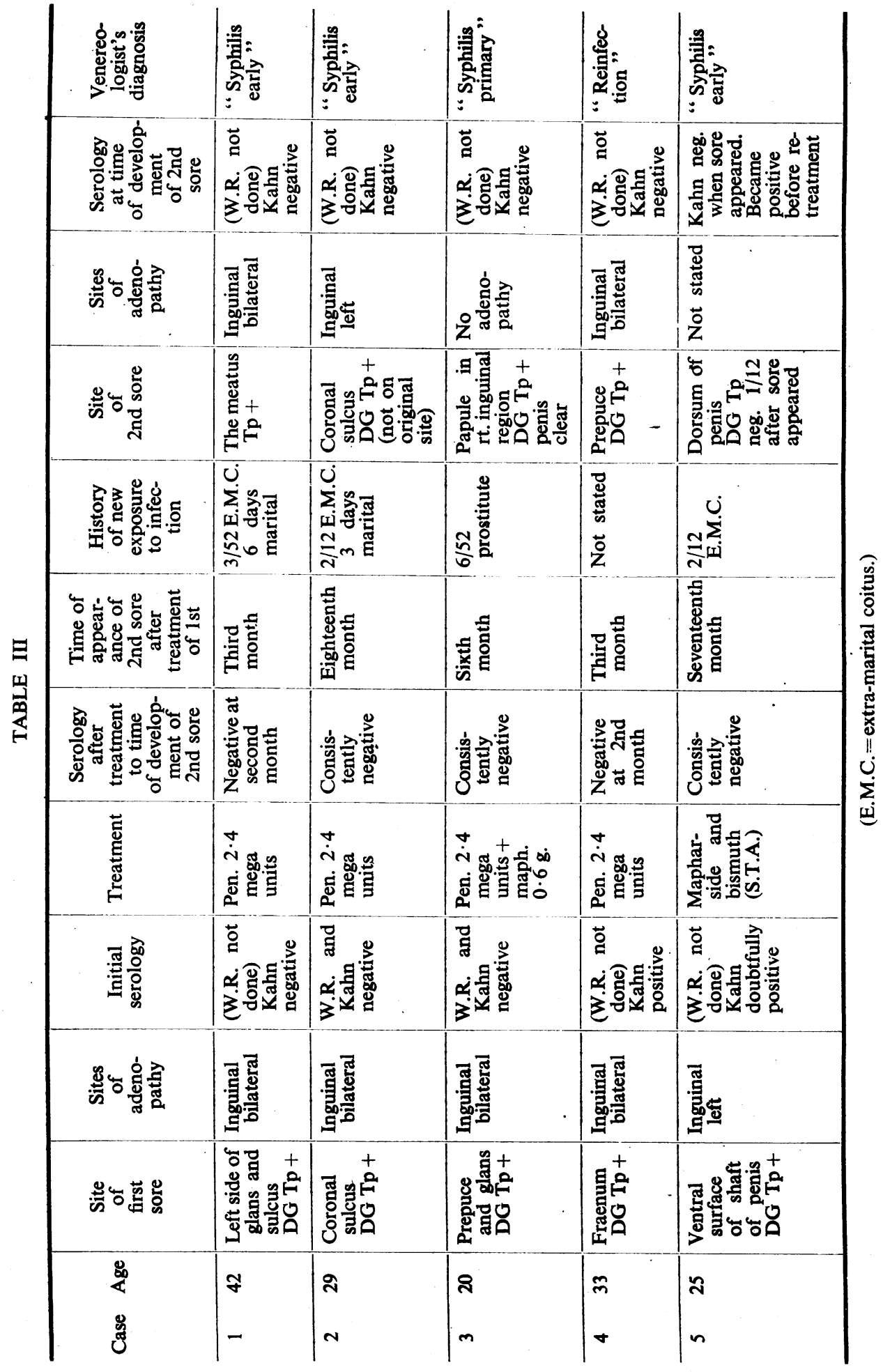

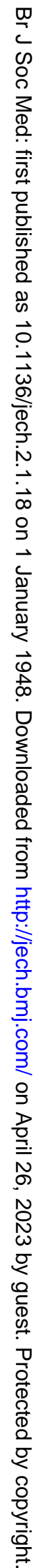


It is worthwhile to point out that there is only one arbitrary assumption in the above relation, that is to say, a linear rate of default in the interval. Otherwise the relation is exact for the following reason. Suppose that we divide the month into a large number (s) of intervals in each of which the number of defaulters is $d_{m} \div s$. At the beginning of each interval the number of defaulters is thus the same; but their contributions to the total $\left(e_{m}\right)$ of unidentified relapses will be different. The first batch with a month before them can contribute to this total $\mathrm{q}_{\mathrm{m}} \mathrm{d}_{\mathrm{m}} \div \mathrm{s}$. The second batch with a residual fraction of a month equivalent to (s-1) $\div \mathrm{s}$ can contribute only $s-1 q_{\mathrm{m}} d_{\mathrm{m}} \div s^{2}$, and so on. The best estimate of $e_{m}$ is the limiting value of the corresponding sum of the contributions of the batches when $s$ is indefinitely large, that is:

$$
\begin{aligned}
& e_{m}=L t \stackrel{q_{m} d_{m}}{s^{2}}\{s+\overline{s-1}+\bar{s}-2 \ldots \ldots 2+1\} \\
& \therefore e_{m}=\frac{1}{2} q_{m} d_{m} .
\end{aligned}
$$

Hence by (i) above

$$
e_{m}=\frac{1}{2}\left(x_{m-1}-x_{m}-y_{m}\right) \quad \cdot q_{m}
$$

Likewise by (ii) above

$$
q_{m}=\frac{y_{m}+\frac{1}{2} q_{m}\left(x_{m-1}-x_{m}-y_{m}\right)}{. x_{m-1}} \ldots \ldots
$$

$\therefore 2 \mathrm{q}_{\mathrm{m}} \cdot \mathrm{x}_{\mathrm{m}-1}=2 \mathrm{y}_{\mathrm{m}}+\mathrm{q}_{\mathrm{m}} \mathrm{x}_{\mathrm{m}-1}-\mathrm{q}_{\mathrm{m}} \mathrm{x}_{\mathrm{m}}-\mathrm{q}_{\mathrm{m}} \mathrm{y}_{\mathrm{m}}$

$$
\begin{aligned}
& \therefore \mathrm{q}_{\mathrm{m}}\left(\mathrm{x}_{\mathrm{m}-1}+\mathrm{x}_{\mathrm{m}}+\mathrm{y}_{\mathrm{m}}\right)=2 \mathrm{y}_{\mathrm{m}} \\
& \therefore \mathrm{q}_{\mathrm{m}}=\frac{2 \mathrm{y}_{\mathrm{m}}}{\mathrm{x}_{\mathrm{m}-1}+\mathrm{z}_{\mathrm{m}}+\mathrm{y}_{\mathrm{m}}}
\end{aligned}
$$

The appropriate computing scheme for the estimation of $\mathrm{q}_{\mathrm{m}}$ is thus:

$$
\begin{aligned}
& \text { Date by Residual Serologi- Defaul- } q_{\mathrm{m}} \\
& \text { month sero-nega- cal ters from from ( } v \text { ) } \\
& \text { (1st day tive relapses equation } \\
& \text { of) population } \\
& 0 \quad \mathrm{x}_{0} \\
& \ldots \ldots \ldots \ldots, y_{1} \ldots \ldots d_{1} \ldots \ldots \quad q_{1} \\
& 1 \quad \mathrm{x}_{1} \\
& \ldots \ldots \ldots \ldots \ldots, \mathrm{y}_{2} \ldots \ldots \mathrm{d}_{2} \ldots \ldots \quad \mathrm{q}_{2} \\
& 2 \quad \mathrm{x}_{2} \\
& \mathbf{x}_{2} \\
& \mathbf{x}_{3}
\end{aligned}
$$

Corresponding to $q_{m}$ the relapse rate, the survival rate $s_{m}$ showing the chance of remaining negative throughout the month $m$ is given by:

$$
s_{m}=1-q_{m}
$$

The chance of remaining sero-negative to the end of the $m$ th month from the beginning of the followup is the combined product

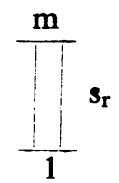

With a computing machine the effort involved in extracting the continued product is small; but it is not a necessary operation and the two methods of arriving at a result should be the same. The second is to proceed thus:

$\begin{array}{cccc}\begin{array}{c}\text { Residual } \\ \text { sero-nega- } \\ \text { tives } \\ \mathrm{x}_{0}\end{array} & \begin{array}{c}\text { Observed } \\ \text { relapses }\end{array} & \begin{array}{c}\text { Estimated } \\ \text { relapses }\end{array} & \begin{array}{c}\text { Cumulative } \\ \text { estimated } \\ \text { relapses }\end{array} \\ \mathrm{x}_{1} & \mathrm{y}_{1} & \mathrm{y}_{1}+\mathrm{e}_{1} & \mathrm{y}_{1}+\mathrm{e}_{1} \\ & \mathrm{y}_{2} & \mathrm{y}_{2}+\mathrm{e}_{2} & \sum_{1}^{2}\left(\mathrm{y}_{\mathrm{r}}+\mathrm{e}_{\mathrm{r}}\right)\end{array}$

Thus the cumulative relapse rate during $\boldsymbol{m}$ months as a percentage is:

$$
100 \sum_{1}^{m}\left(y_{r}+e_{r}\right) \div x_{0}
$$

This should be equal to:

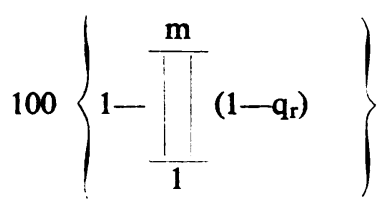

in which $\left(1-q_{r}\right)=s_{r}$ of the preceding development.

\section{Particulars of Treatments}

Cases which received penicillin fall into the following groups:

1. $2 \cdot 4$ mega units of sodium penicillin by three-hourly intramuscular injections of 40,000 Oxford units over a period of $7 \frac{1}{2}$ days with no treatment other than local applications of saline or occasionally Eusol and other antiseptics to lesions; 
2. 4.0 mega units of sodium penicillin given as above but for $12 \frac{1}{2}$ days;

3. $2 \cdot 4$ mega units of sodium penicillin in $7 \frac{1}{2}$ days with a course of intensive arsenotherapy beginning on the second day of penicillin treatment, viz. mapharside $0.06 \mathrm{~g}$. intravenously daily for a period of 10 days;

4. $2 \cdot 4$ mega units of penicillin, $0 \cdot 4 \mathrm{~g}$. mapharside, and $1.0 \mathrm{~g}$. bismuth given concurrently as above (3) over a period of 10 days.

Standard commercial preparations were used. The proportions of the different crystalline penicillins in these preparations are not known.

"Long-term" arsenic cases call for more detailed specification. Ostensibly, it was the policy to treat all cases of: (a) primary syphilis with at least four courses of arsenic and bismuth given concurrently in a twelve-month period, each course consisting of $5.85 \mathrm{~g}$. of N.A.B. and $2.0 \mathrm{~g}$. of bismuth; (b) secondary syphilis with at least five courses of arsenic and bismuth. In practice, it rarely proved possible to implement this procedure consistently. In fact, cases in our series treated with apparent success receiyed from between 3 to 27 g. N.A.B. and 3 to $18 \mathrm{~g}$. of bismuth over periods varying from 8 to 23 months. Documentation with respect to some cases was poor, only the number of courses being stated. Other long-term cases received, in addition to N.A.B. and bismuth, two weekly injections of $0.06 \mathrm{~g}$. mapharside in place of a single injection of $0.6 \mathrm{~g}$. N.A.B. Cases receiving mercurials ( 3 per cent. of all) were rejected from the pool of data. The composition of the group was as follows:

$\%$

(437 cases)

\begin{tabular}{|c|c|c|}
\hline $\begin{array}{l}\text { N.A.B. } \\
\text { Bi. }\end{array}$ & $\begin{array}{r}\text { No. of courses and } \\
\text { dosage known }\end{array}$ & 61 \\
\hline $\begin{array}{l}\text { N.A.B. } \\
\text { Bi. } \\
\text { mapharside }\end{array}$ & $\begin{array}{r}\text { No. of courses and } \\
\text { dosage known }\end{array}$ & $16 \cdot 6$ \\
\hline \multirow{2}{*}{$\begin{array}{l}\text { N.A.B. } \\
\text { Bi. } \\
\text { mapharside }\end{array}$} & $\begin{array}{l}\text { No. of courses known. } \\
\text { Dosage not stated }\end{array}$ & $22 \cdot 4$ \\
\hline & & $100 \cdot 0$ \\
\hline
\end{tabular}

Cases which received mapharside and cases for which treatment dosage was not fully stated make up more than a third of the total material available. So it was decided to retain them. In specifying the equivalent dosage of N.A.B. received by such cases, we equate $0.12 \mathrm{~g}$. of mapharside to $0.6 \mathrm{~g}$. N.A.B.

\section{TABLE IV}

MEAn Value in Grammes for N.A.B. AND Bismuth aND Mean Value in months for Period of Treatment in Cases Receiving four COURSES OF N.A.B. AND Bismuth

\begin{tabular}{|c|c|c|c|c|}
\hline Diagnosis & $\begin{array}{l}\text { No. of } \\
\text { cases }\end{array}$ & $\begin{array}{c}\text { Mean } \\
\text { dose } \\
\text { N.A.B. } \\
\text { (g.) }\end{array}$ & $\begin{array}{c}\text { Mean } \\
\text { dose } \\
\text { bismuth } \\
\text { (g.) }\end{array}$ & $\begin{array}{c}\text { Mean } \\
\text { duration } \\
\text { of } \\
\text { treatment } \\
\text { (months) }\end{array}$ \\
\hline $\begin{array}{l}\text { Primary: } \\
\text { sero- } \\
\text { negative } \\
\text { Primary: } \\
\text { sero- } \\
\text { positive }\end{array}$ & 36 & $\begin{array}{l}19 \cdot 5 \pm 0 \cdot 6 \\
19 \cdot 0 \pm 0 \cdot 5\end{array}$ & $\begin{array}{l}9 \cdot 3 \pm 1 \cdot 3 \\
9 \cdot 5 \pm 0 \cdot 4\end{array}$ & $\begin{array}{l}13 \cdot 2 \pm 0 \cdot 5 \\
13 \cdot 7 \pm 0 \cdot 6\end{array}$ \\
\hline Secondary & 38 & $19 \cdot 0 \pm 0 \cdot 2$ & $9 \cdot 7 \pm 0.5$ & $14 \cdot 1 \pm 0 \cdot 5$ \\
\hline
\end{tabular}

and add the quantity of N.A.B. so computed to the actual amount of N.A.B. received.

From analysis (Table IV) of dosage given in four courses to cases with reference to which the information was available, it was possible to distribute the L.T.A. cases among two groups: (i) group A cases receiving more than 19.0 g. of N.A.B. or, where

TABLE VA

ANALYSIS OF CASES RECEIVING MORE THAN 19.0 g. N.A.B. PLUS BISMUTH

\begin{tabular}{c|c|c|c|c}
\hline Diagnosis & $\begin{array}{c}\text { No. of } \\
\text { cases }\end{array}$ & $\begin{array}{c}\text { Mean } \\
\text { dose } \\
\text { N.A.B. } \\
\text { (g.) }\end{array}$ & $\begin{array}{c}\text { Mean } \\
\text { dose } \\
\text { bismuth } \\
(\mathrm{g} .)\end{array}$ & $\begin{array}{c}\text { Mean } \\
\text { duration } \\
\text { of } \\
\text { treatment } \\
\text { (months) }\end{array}$ \\
\hline $\begin{array}{c}\text { Primary: } \\
\text { sero- } \\
\text { negative }\end{array}$ & 28 & $22 \cdot 1 \pm 0.9$ & $9 \cdot 5 \pm 0.6$ & $14 \cdot 1 \pm 0.9$ \\
$\begin{array}{c}\text { Primary: } \\
\text { sero- } \\
\text { positive }\end{array}$ & 50 & $22 \cdot 1 \pm 0.4$ & $9 \cdot 7 \pm 0.2$ & $13 \cdot 7 \pm 0.4$ \\
Secondary & 52 & $22 \cdot 3 \pm 0.3$ & $10 \cdot 2 \pm 0.4$ & $14 \cdot 7 \pm 0.4$ \\
\hline & \multicolumn{4}{c}{ TABLE VB }
\end{tabular}

ANALYSIS OF CASES RECEIVING LeSS than $19 \cdot 0$ g. N.A.B. PLUS BISMUTH

\begin{tabular}{c|c|c|c|c}
\hline Diagnosis & $\begin{array}{c}\text { No. of } \\
\text { cases }\end{array}$ & $\begin{array}{c}\text { Mean } \\
\text { dose } \\
\text { N.A.B. } \\
\text { (g.) }\end{array}$ & $\begin{array}{c}\text { Mean } \\
\text { dose } \\
\text { bismuth } \\
(\mathrm{g} .)\end{array}$ & $\begin{array}{c}\text { Mean } \\
\text { duration } \\
\text { of } \\
\text { treatment } \\
\text { (months) }\end{array}$ \\
\hline $\begin{array}{c}\text { Primary: } \\
\text { sero- } \\
\text { negative }\end{array}$ & 75 & $13.0 \pm 0.5$ & $8.7 \pm 0.2$ & $12 \cdot 2 \pm 0.4$ \\
$\begin{array}{c}\text { Primary: } \\
\text { sero- } \\
\text { positive }\end{array}$ & 81 & $14.4 \pm 0.3$ & $9.8 \pm 0.2$ & $14 \cdot 1 \pm 0.4$ \\
\hline Secondary & 53 & $13.4 \pm 0.6$ & $9.5 \pm 0.4$ & $14.0 \pm 0.4$ \\
\hline
\end{tabular}


dosage was not stated, four or more courses of arsenic and bismuth; (ii) group B cases receiving either less than $19.0 \mathrm{~g}$. of arsenic or less than four courses of arsenic and bismuth. Tables VA and VB show that the only obviously significant difference between these groups is the dosage of arsenic.

As a result of this analysis, 79 cases receiving between four and six courses of arsenic and bismuth were added to group $\mathrm{A}$, whilst 19 cases receiving between two and three courses only were added to group B. No significant departures from these mean values occurred among cases which were known to have relapsed in the two groups. Analysis of group A and B cases with reference to the incidence of jaundice revealed a highly significant difference (Table VI) between the two groups. This was, of course, the prime reason for the lower average arsenic dose in group $B$. The incidence of dermatitis was also higher in this group, though it was a minor contributory factor in lowering the arsenic dosage for the group. Differences with reference to incidence of jaundice between the three subdivisions within each group are not statistically significant, though examination of a larger series of cases has shown that maximum susceptibility to jaundice occurs during the very early stage of syphilis.

A group of "long-term" arsenic cases subsequently treated with penicillin started treatment on a

TABLE VI

$\%$ JAUNDICED

\begin{tabular}{|c|c|c|c|c|}
\hline & $\begin{array}{c}\text { No. of } \\
\text { cases }\end{array}$ & $\begin{array}{l}\text { Primary } \\
\text { sero- } \\
\text { negative }\end{array}$ & $\begin{array}{l}\text { Primary } \\
\text { sero- } \\
\text { positive }\end{array}$ & Secondary \\
\hline $\begin{array}{l}\text { Group } A \\
\text { Group B }\end{array}$ & $\begin{array}{l}209 \\
228\end{array}$ & $\begin{array}{l}15 \cdot 2 \\
54 \cdot 3\end{array}$ & $\begin{array}{l}27 \cdot 8 \\
60 \cdot 6\end{array}$ & $\begin{array}{l}20 \cdot 5 \\
45 \cdot 2\end{array}$. \\
\hline
\end{tabular}

TABLE VII

Mean Quantities of ARSENIC and Bismuth Recerved PRIOR TO PENICILLIN THERAPY

\begin{tabular}{|c|c|c|c|c|}
\hline Diagnosis & $\begin{array}{l}\text { No. of } \\
\text { cases }\end{array}$ & $\begin{array}{c}\text { Mean } \\
\text { dose } \\
\text { N.A.B. } \\
\text { (g.) }\end{array}$ & $\begin{array}{c}\text { Mean } \\
\text { dose } \\
\text { bismuth } \\
\text { (g.) }\end{array}$ & \begin{tabular}{|c|} 
Mean \\
duration \\
of \\
treatmen \\
(including \\
penicillin) \\
(months)
\end{tabular} \\
\hline $\begin{array}{l}\text { Primary: } \\
\text { sero- } \\
\text { negative } \\
\text { Primary: } \\
\text { sero- } \\
\text { positive }\end{array}$ & 25 & $\begin{array}{l}7 \cdot 7 \pm 0 \cdot 6 \\
7 \cdot 1 \pm 0 \cdot 5\end{array}$ & $\begin{array}{l}4 \cdot 1 \pm 0 \cdot 4 \\
4 \cdot 1 \pm 0 \cdot 5\end{array}$ & $\begin{array}{l}6 \cdot 4 \pm 0 \cdot 8 \\
7 \cdot 0 \pm 0 \cdot 7\end{array}$ \\
\hline Secondary & 26 & $7 \cdot 9 \pm 0 \cdot 7$ & $4 \cdot 8 \pm 0 \cdot 6$ & $7 \cdot 1 \pm 0 \cdot 1$ \\
\hline
\end{tabular}

purely "long-term" arsenic basis, but after a variable interval arsenotherapy was stopped; and they were given a routine course of penicillin, 2.4 mega units in $7 \frac{1}{2}$ days. Table VII shows the mean values for arsenic and bismuth received prior to penicillin therapy, and the mean period over which therapy (including penicillin) took place.

It can be seen that similar amounts of N.A.B. and bismuth were given throughout and that the period between the beginning of arsenotherapy and the end of penicillin injections was not unduly variable. Amongst cases which are known to have relapsed there were no significant departures from the mean values given above. The three divisions into primary sero-negative, primary sero-positive, and secondary cases refers to the condition at the inception of arsenotherapy. By the time penicillin therapy began, most of the initially sero-positive cases had become sero-negative. Table VIII indicates the proportion of cases in which seroreversal had taken place, those in which the serum test was still positive, and those who had not had a recent test.

\section{TABLE VIII}

Serology at Start of Penicillin Therapy

\begin{tabular}{c|c|c|c|c}
\hline $\begin{array}{c}\text { Initial } \\
\text { diagnosis }\end{array}$ & $\begin{array}{c}\text { No. of } \\
\text { cases }\end{array}$ & $\begin{array}{c}\text { Negative } \\
\%\end{array}$ & $\begin{array}{c}\text { Positive } \\
\%\end{array}$ & $\begin{array}{c}\text { Insufficient } \\
\text { data } \\
\%\end{array}$ \\
\hline $\begin{array}{c}\text { Primary: } \\
\text { sero- } \\
\text { negative }\end{array}$ & 25 & 100 & 0.0 & 0.0 \\
$\begin{array}{c}\text { Primary: } \\
\text { sero- } \\
\text { positive }\end{array}$ & 38 & $64 \cdot 1$ & 10.3 & 25.6 \\
Secondary & 26 & $80 \cdot 8$ & 11.5 & 7.7 \\
\hline
\end{tabular}

Cases which received short-term arsenic therapy fell into two groups. The first group comprised cases treated by daily intravenous injections of mapharside of $0.06 \mathrm{~g}$. and intramuscular injection of bismuth over a period of 20 days. On inspection the cases consistently received a total of $2.0 \mathrm{~g}$. bismuth and the treatment period was 20 days with

TABLE IX

\begin{tabular}{cc|c|c}
\hline \multicolumn{1}{c|}{ Diagnosis } & No. of cases & $\begin{array}{c}\text { Mean dose } \\
\text { mapharside } \\
\text { (g.) }\end{array}$ \\
\hline \begin{tabular}{ll|c} 
Primary: \\
sero-negative
\end{tabular} &. & 32 & $1 \cdot 31$ \\
$\begin{array}{l}\text { Primary: } \\
\text { sero-positive }\end{array}$ &. & 38 & $1 \cdot 30$ \\
Secondary $\quad .$. &. & 42 & $1 \cdot 29$ \\
\hline
\end{tabular}




\section{TABLE $X$}

Percentage Relapse Rates

Maximum values shown below were calculated by regarding doubtful cases as relapses, minimum values by regarding such cases as cures. Figures before the sign $\mp$ are thus the means of the maximum and minimum rates and include one half of the doubtful cases.

\begin{tabular}{|c|c|c|c|c|c|c|c|c|c|}
\hline & $\begin{array}{c}\text { Time period } \\
\text { (months) }\end{array}$ & Pen. $2 \cdot 4 \mathrm{Mu}$ & Pen. $4 \cdot 0 \mathrm{Mu}$ & $\begin{array}{c}\text { Pen. } 2.4 \mathrm{Mu} \\
\text { and maph. } \\
0.6 \mathrm{~g} .\end{array}$ & $\begin{array}{l}\text { Pen. } 2.4 \mathrm{Mu} \\
\text { maph. } 0.4 \mathrm{~g} . \\
\text { bi. } 1.0 \mathrm{~g} .\end{array}$ & $\begin{array}{l}\text { L.T.A. } 7 \mathrm{~g} \text {, } \\
\text { pen. } 2 \cdot 4 \mathrm{Mu}\end{array}$ & $\begin{array}{l}\text { L.T.A. (A) } \\
\text { (N.A.B. 22 g. } \\
\text { Bi. 9g.) }\end{array}$ & $\begin{array}{l}\text { L.T.A. (B) } \\
\text { (N.A.B. } 14 \mathrm{~g} . \\
\text { Bi. } 9 \mathrm{g.} \text {.) }\end{array}$ & $\begin{array}{c}\text { S.T.A. } \\
\left(\begin{array}{l}\text { maph. 1.3 g., } \\
\text { bi. } 2.0 \mathrm{~g} .)\end{array}\right.\end{array}$ \\
\hline $\begin{array}{l}\text { Primary } \\
\text { sero- } \\
\text { negative }\end{array}$ & $\begin{array}{r}6 \\
12 \\
18\end{array}$ & $\begin{array}{c}11 \cdot 0 干 0.5 \\
14 \cdot 0 干 2.4 \\
(20 \cdot 7 干 2.2)\end{array}$ & $\begin{array}{c}(10.8 \mp 0.8) \\
-\end{array}$ & $\begin{array}{c}14 \cdot 6 \mp 1 \cdot 5 \\
(18 \cdot 2 \mp 1 \cdot 5)\end{array}$ & $\begin{array}{c}5 \cdot 0 \mp 0.0 \\
(9 \cdot 0 \mp 1 \cdot 9) \\
-\end{array}$ & $\left(\begin{array}{c}(0 \cdot 0) \\
(5 \cdot 7 \neq 0 \cdot 0)\end{array}\right.$ & $\begin{array}{c}0.0 \\
(0.0) \\
-\end{array}$ & $\begin{array}{c}0 \cdot 0 \\
(0 \cdot 0) \\
(0.0)\end{array}$ & $\begin{array}{c}0.0 \\
(0.0) \\
-\end{array}$ \\
\hline $\begin{array}{l}\text { Primary } \\
\text { sero- } \\
\text { positive }\end{array}$ & $\begin{array}{r}6 \\
12 \\
18\end{array}$ & $\begin{array}{c}10 \cdot 2 \mp 0.0 \\
12 \cdot 8 \mp 0.0 \\
(14 \cdot 1 \mp 1 \cdot 3)\end{array}$ & $\begin{array}{c}(6.3 \mp 0.0) \\
-\end{array}$ & $\begin{array}{c}6 \cdot 7 \mp 0.9 \\
(15 \cdot 9 \mp 4 \cdot 5) \\
-\end{array}$ & $\begin{array}{c}10 \cdot 9 \mp 0.0 \\
(23 \cdot 3 \mp 3 \cdot 3) \\
-\end{array}$ & $\begin{array}{c}2.6 \mp 0.0 \\
(2.6 \mp 0.0) \\
\end{array}$ & $\begin{array}{c}0.0 \\
1.670 .0 \\
-\end{array}$ & $\begin{array}{c}0.6 \mp 0.6 \\
3.5 \mp 0.6 \\
-\end{array}$ & $\begin{array}{c}5 \cdot 3 \mp 0.0 \\
(5 \cdot 3 \mp 0.0) \\
(17 \cdot 8 \mp 2 \cdot 5)\end{array}$ \\
\hline Secondary & $\begin{array}{r}6 \\
12 \\
18 \\
\end{array}$ & $\begin{array}{c}8 \cdot 1 \text { 干0.5 } \\
17 \cdot 5 干 0.5 \\
-\end{array}$ & $\begin{array}{c}(17 \cdot 4 \mp 0 \cdot 0) \\
-\end{array}$ & $\begin{array}{c}(6.6 干 0.0) \\
-\end{array}$ & $\begin{array}{c}(19 \cdot 2 \mp 0 \cdot 0) \\
-\end{array}$ & $\begin{array}{c}(8 \cdot 8 \mp 0 \cdot 0) \\
(12.9 干 4 \cdot 1) \\
-\end{array}$ & $\begin{array}{c}4 \cdot 1 \mp 0.9 \\
(11 \cdot 4 \mp 2 \cdot 1)\end{array}$ & $\begin{array}{c}3 \cdot 8 \mp 1 \cdot 2 \\
(9 \cdot 3 \mp 2 \cdot 8) \\
-\end{array}$ & $\begin{array}{c}5 \cdot 7 \mp 0.0 \\
(10 \cdot 7 \mp 1 \cdot 5) \\
(16.8 \mp 3 \cdot 7)\end{array}$ \\
\hline
\end{tabular}

Bracketed figures are based on samples of less than 30 cases

exceptional and minor variations (e.g. $\pm 0.2 \mathrm{~g}$. bismuth and \pm 1 . day respectively). Mapharside dosage varied between $1 \cdot 2 \mathrm{~g}$. and $1.6 \mathrm{~g}$. for the course. Table IX shows, however, that the mean dosage was $1 \cdot 3 \mathrm{~g}$.

The second group comprised only about 40 cases treated by semi-intensive courses of mapharside, or neohalarsen, and bismuth over a minimum period of thirty days. The variability of dosage and treatment period were, however, too great to allow of standardization in such a small group of cases. We therefore present the relapse rates for the twenty-day treatment group only.

\section{Results}

Appendix 1 cites crude figures with reference to relapses, and failures and doubtful cases; and Appendix 2 cites cases remaining at the end of specified intervals after end of treatment. Table $\mathbf{X}$ shows cumulative relapse rates at the end of six and twelve months for the different treatments. With regard to some, it was possible to follow sufficient cases for eighteen months. Figures can be regarded only as trends owing to the small size of some samples. All failures as defined above have been excluded. It is evident that the penicillin courses are comparatively unsuccessful except when following long-term arsenic. The two L.T.A. schemes are apparently the most efficient, particularly for treatment of primary syphilis, and in contrast to other forms of therapy are the most successful treatments of secondary syphilis. Shortterm arsenotherapy takes an intermediate position.

It is interesting to note the comparative relapse rates of S.T.A. (mapharside $1.3 \mathrm{~g}$. and bismuth 2.0 g.) with: (a) penicillin 2.4 mega units and mapharside $0.6 \mathrm{~g}$., and $(b)$ penicillin 2.4 mega units and mapharside $0.4 \mathrm{~g}$. + bismuth $1.0 \mathrm{~g}$. Duration of treatment was much the same for each of these therapies. The relapse rates of S.T.A. are consistently smaller than those of either form of combined therapy. The least difference occurred in cases of sero-positive primary and in cases of secondary syphilis between S.T.A. and penicillin 2.4 mega units and mapharside $0.6 \mathrm{~g}$. Since penicillin alone, in the two dosage schemes investigated, is least efficacious of all, these relapse rates suggest that penicillin may in some way mitigate the effect of arsenic on Treponema pallidum. It is, however, necessary to point out that the dosage of mapharside received by the S.T.A. group was at least twice as great as that given to the penicillin cases.

TABLE XI

Analysis of Treatment Failure Cases

Percentage of treatment failure cases (defined as cases remaining persistently sero-positive for four months or more after treatment) as a percentage of total numbers of cases (within each treatment).

\begin{tabular}{|c|c|c|c|c|c|c|c|c|}
\hline & $\begin{array}{c}\text { Pen. } \\
2 \cdot 4 \mathrm{Mu}\end{array}$ & $\begin{array}{l}\text { Pen. } \\
\text { 4.0 Mu }\end{array}$ & $\begin{array}{c}\text { Pen. } \\
2 \cdot 4 \mathrm{Mu} \\
\text { and maph. } \\
6 \cdot 0\end{array}$ & $\begin{array}{c}\text { Pen. } \\
2 \cdot 4 \mathrm{Mu} \text {, } \\
\text { maph. } \\
0 \cdot 4 \mathrm{~g} . \\
\text { bi. } 1.0 \mathrm{~g} .\end{array}$ & $\begin{array}{c}\text { LTA } \\
7 \text { g. and } \\
\text { Pen. } \\
2 \cdot 4 \mathrm{Mu}\end{array}$ & $\begin{array}{c}\text { LTA } \\
\text { (A) } \\
\text { NAB 22 g. } \\
\text { Bi. } 9 \text { g. }\end{array}$ & $\begin{array}{c}\text { LTA } \\
\text { (B) } \\
\text { NAB 14g. } \\
\text { Bi. } 9 \mathrm{~g} .\end{array}$ & $\begin{array}{c}\text { STA } \\
\begin{array}{c}1 \cdot 3 \mathrm{~g} . \\
\text { bi. } 2 \cdot 0 \mathrm{~g} .\end{array}\end{array}$ \\
\hline Primary sero-positive & $2.9 \mp 0.0$ & $1 \cdot 6 \mp 1 \cdot 6$ & $0.8 \mp 0.8$ & $5 \cdot 5 \mp 0.8$ & $0 \cdot 0$ & 0.0 & 0.0 & 0.0 \\
\hline Secondary $\quad \therefore$ & $7 \cdot 8 \mp 3 \cdot 2$ & $3 \cdot 8 \mp 3 \cdot 8$ & $2 \cdot 5 \mp 2 \cdot 5$ & $2 \cdot 8 \mp 2 \cdot 8$ & 0.0 & 0.0 & $5 \cdot 0 \mp 0 \cdot 0$ & $10 \cdot 7 \mp 6 \cdot 0$ \\
\hline
\end{tabular}


Our data sustain the accepted conclusion that the prognosis for arsenotherapy is less favourable if treatment does not start until the sero-positive primary stage. Contrary to results reported by Moore (1943) and others, they would also suggest that the prognosis for sero-positive primary cases is better than that for secondary cases. Our results do not suggest any consistent differences in these respects with regard to penicillin therapy. Although attenuation of our material owing to the introduction of penicillin shortly before demobilization compels us to state only guarded conclusions with respect to the long-term prognosis of penicillin therapy, the picture disclosed by the diagram suggests that the risk of relapse among cases treated in the primary stage reaches a limiting value of about 14 per.cent. within the first twelve months.

Our definition excludes the occurrence of failures among sero-negative primary cases. Table XI shows an analysis of those cases remaining seropositive for four or more months. Penicillin has a comparatively higher rate of failure among seropositive primary cases, but among secondary cases, particularly when combined with mapharside, compares not unfavourably with S.T.A. and the smaller dosage group (B) of L.T.A. For most treatments the prognosis in this respect of secondary cases is less favourable than the prognosis of primary cases.

\section{SUMMARY}

Relapse rates during a twelve-month period of cases of early syphilis respectively treated with eight different therapies are contrasted and disclose the following conclusions:

1. Long-term arsenic in a mean dosage of $22 \mathrm{~g}$.
N.A.B. given in four or more courses proved to be the most effective therapy for all forms of early syphilis. In dosages averaging $14 \mathrm{~g}$. in fewer than four courses, it was the next most efficacious.

2. For primary cases in the doses, and for the period, specified in the text, penicillin alone was inferior to either long-term or short-term arsenotherapy both with respect to prognosis of relapse and resistance to treatment.

3. The data of this enquiry give no conclusive indications of synergism with reference to simultaneous use of penicillin and arsenicals with bismuth, being suggestive, if at all, of the reverse.

4. Though the data recorded admittedly antedate recognition of the importance of the $\mathrm{K}$-fraction, the results at least emphasize the need for long-term follow-up before replacing arsenotherapy by penicillin.

5. On the other hand, it is necessary to admit the possibility that greater frequency and/or duration of penicillin treatment in contradistinction to greater aggregate dosage might reverse the unfavourable verdict which our data compel us to record.

We are indebted to the Director General, Army Medical Services, for permission to publish this paper, and to Prof. Lancelot Hogben, F.R.S., for much help and advice. Our thanks are also due to Lt.-Col. R. R. Willcox, R.A.M.C. and Lt.-Col. J. W. Eames, R.A.M.C., Advisers in Venereology to the Army, for their willing co-operation.

REFERENCES

Rabut and Hudelo (1924). Presse Méd., 32, 740.

Moore, J. E. (1943). "The Modern Treatment of Syphilis." Springfield, Illinois.

Truelove, S. C., and Hogben, L. (1947). Brit. J. soc. Med., 1, 18 .

\section{APPENDIX 1}

The relative distribution of relapses and treatment failures in the various treatment groups and their subdivision into primary sero-negative, primary sero-positive, and secondary cases. Space does not permit of indication of the relationships of relapses to time intervals after treatment. Crude figures.

\begin{tabular}{|c|c|c|c|c|c|c|c|c|c|c|c|c|c|}
\hline & \multicolumn{3}{|c|}{ Primary sero-negative } & \multicolumn{5}{|c|}{ Primary sero-positive } & \multicolumn{5}{|c|}{ Secondary } \\
\hline & $\underset{\text { relapse }}{\text { Clin. }}$ & $\begin{array}{l}\text { Definite } \\
\text { sero- } \\
\text { relapse }\end{array}$ & $\begin{array}{c}\text { Doubtful } \\
\text { sero- } \\
\text { relapse }\end{array}$ & $\begin{array}{l}\text { Clin. } \\
\text { relapse }\end{array}$ & $\begin{array}{c}\text { Definite } \\
\text { sero- } \\
\text { relapse }\end{array}$ & $\begin{array}{c}\text { Doubtful } \\
\text { sero- } \\
\text { relapse }\end{array}$ & $\begin{array}{c}\text { Definite } \\
\text { treatment } \\
\text { failures }\end{array}$ & $\begin{array}{c}\text { Doubtful } \\
\text { treatment } \\
\text { failures }\end{array}$ & $\begin{array}{c}\text { Clin. } \\
\text { relapse }\end{array}$ & $\begin{array}{l}\text { Definite } \\
\text { sero- } \\
\text { relapse }\end{array}$ & $\begin{array}{c}\text { Doubtful } \\
\text { sero- } \\
\text { relapse }\end{array}$ & $\begin{array}{c}\text { Definite } \\
\text { treatment } \\
\text { failures }\end{array}$ & $\begin{array}{l}\text { Doubtful } \\
\text { treatment } \\
\text { failures }\end{array}$ \\
\hline Pen. $2 \cdot 4$ & 11 & 1 & 3 & 15 & 3 & 1 & 4 & 0 & 8 & 4 & 2 & 5 & 7 \\
\hline Pen. 4.0 & 5 & 0 & 1 & 1 & 0 & 0 & 0 & 1 & 2 & 1 & 0 & 0 & 1 \\
\hline Pen. and maph. & 10 & 1 & 2 & 5 & 1 & 3 & 0 & 1 & 3 & 0 & 0 & 0 & 2 \\
\hline $\begin{array}{c}\text { Pen., maph., and } \\
\text { bi. } \quad . .\end{array}$ & 5 & 0 & 1 & 6 & 1 & 1 & 3 & 1 & 6 & 1 & 0 & 0 & 2 \\
\hline LTA and pen. & 2 & 0 & 0 & 2 & 0 & 0 & 0 & 0 & 0 & 3 & 1 & 0 & 0 \\
\hline LTA (A) & 0 & 0 & 0 & 0 & 1 & 0 & 0 & 0 & 0 & 0 & 6 & 0 & 0 \\
\hline LTA (B) & 0 & 0 & 0 & 1 & 1 & 0 & 0 & 0 & 0 & 4 & 0 & 2 & 0 \\
\hline STA $\quad \therefore$ & 0 & 0 & 0 & 2 & 2 & 2 & 0 & 0 & 1 & 5 & 0 & 2 & 5 \\
\hline Total $\ldots$ & 33 & 2 & 7 & 32 & 9 & 7 & 7 & 3 & 20 & 18 & 9 & 9 & 17 \\
\hline
\end{tabular}




\section{APPENDIX 2}

Numbers of cases in each treatment group (subdivided into primary sero-negative, primary sero-positive, and secondary) and the numbers of cases remaining under surveillance after six and twelve months.

It will be noted that relatively small numbers of cases in the LTA, LTA + Pen., and STA groups were, in general, followed over a longer period than the other cases.

\begin{tabular}{|c|c|c|c|c|c|c|c|c|c|c|}
\hline & & $\begin{array}{l}\text { Pen. } \\
2 \cdot 4\end{array}$ & $\begin{array}{c}\text { Pen. } \\
4 \cdot 0\end{array}$ & $\begin{array}{l}\text { Pen. } \\
\text { and } \\
\text { maph. }\end{array}$ & $\begin{array}{l}\text { Pen., } \\
\text { maph., } \\
\text { and bi. }\end{array}$ & $\begin{array}{l}\text { LTA } \\
\text { and } \\
\text { pen. }\end{array}$ & $\begin{array}{c}\text { LTA } \\
\text { (A) }\end{array}$ & $\begin{array}{c}\text { LTA } \\
\text { (B) }\end{array}$ & STA & \\
\hline \multirow{3}{*}{$\begin{array}{l}\text { Primary } \\
\text { sero-negative }\end{array}$} & $\begin{array}{l}\text { Total } \\
\text { treated }\end{array}$ & 114 & 57 & 108 & 105 & 25 & 44 & 75 & 32 & \\
\hline & $\begin{array}{l}\text { Remain- } \\
\text { ing } 6 / 12\end{array}$ & 80 & 20 & 30 & 51 & 23 & 30 & 64 & 31 & \\
\hline & $\begin{array}{l}\text { Remain- } \\
\text { ing } 12 / 12\end{array}$ & 41 & 0 & 6 & 5 & 8 & 10 & 34 & 23 & \\
\hline \multirow{3}{*}{$\begin{array}{l}\text { Primary } \\
\text { sero-positive }\end{array}$} & $\begin{array}{l}\text { Total } \\
\text { treated }\end{array}$ & 163 & 41 & 110 & 89 & 38 & 84 & 84 & 38 & \\
\hline & $\begin{array}{l}\text { Remain- } \\
\text { ing } 6 / 12\end{array}$ & 122 & 14 & 31 & 42 & 31 & 64 & 63 & 35 & \\
\hline & $\begin{array}{l}\text { Remain- } \\
\text { ing } 12 / 12\end{array}$ & 52 & 0 & 6 & 2 & 17 & 31 & 31 & 29 & \\
\hline \multirow{3}{*}{ Secondary } & $\begin{array}{l}\text { Total } \\
\text { treated }\end{array}$ & 118 & 28 & 53 & 48 & 26 & 67 & 46 & 42 & \\
\hline & $\begin{array}{l}\text { Remain- } \\
\text { ing } 6 / 12\end{array}$ & 86 & 8 & 25 & 20 & 19 & 48 & 36 & 39 & \multirow[b]{2}{*}{$\begin{array}{c}\text { Total } \\
\text { cases }\end{array}$} \\
\hline & $\begin{array}{l}\text { Remain- } \\
\text { ing } 12 / 12\end{array}$ & 32 & 0 & 5 & 4 & 9 & 26 & 20 & 28 & \\
\hline Total treated & & 395 & 126 & 271 & 242 & 89 & 195 & 205 & 112 & 1,635 \\
\hline
\end{tabular}

